\title{
Correlates of overgeneral memories in normal subjects
}

Citation for published version (APA):

Merckelbach, H. L. G. J., Muris, P., \& Horselenberg, R. (1996). Correlates of overgeneral memories in normal subjects. Behavioural and Cognitive Psychotherapy, 24, 109-115.

https://doi.org/10.1017/S1352465800017379

Document status and date:

Published: 01/01/1996

DOI:

10.1017/S1352465800017379

Document Version:

Publisher's PDF, also known as Version of record

\section{Please check the document version of this publication:}

- A submitted manuscript is the version of the article upon submission and before peer-review. There can be important differences between the submitted version and the official published version of record.

People interested in the research are advised to contact the author for the final version of the publication, or visit the DOI to the publisher's website.

- The final author version and the galley proof are versions of the publication after peer review.

- The final published version features the final layout of the paper including the volume, issue and page numbers.

Link to publication

\footnotetext{
General rights rights.

- You may freely distribute the URL identifying the publication in the public portal. please follow below link for the End User Agreement:

www.umlib.nl/taverne-license

Take down policy

If you believe that this document breaches copyright please contact us at:

repository@maastrichtuniversity.nl

providing details and we will investigate your claim.
}

Copyright and moral rights for the publications made accessible in the public portal are retained by the authors and/or other copyright owners and it is a condition of accessing publications that users recognise and abide by the legal requirements associated with these

- Users may download and print one copy of any publication from the public portal for the purpose of private study or research.

- You may not further distribute the material or use it for any profit-making activity or commercial gain

If the publication is distributed under the terms of Article $25 \mathrm{fa}$ of the Dutch Copyright Act, indicated by the "Taverne" license above, 


\section{Correlates of Overgeneral Memories in Normal Subjects}

\section{Harald Merckelbach, Peter Muris and Robert Horselenberg}

\section{University of Limburg, The Netherlands}

This study examined the correlates of overgeneral memories (i.e., nonspecific memories) in normal subjects. Subjects were instructed to generate five personal memories in response to positive cue-words and five memories in response to negative cue-words. As predicted, no evidence was found for a positive association between overgeneral memories and level of depression. Neither was there an association between low memory specificity on the one hand and neuroticism and trait anxiety on the other hand. A significant though small correlation was found between hemisphere thinking style and specificity of personal memories. Surprisingly, the direction of this correlation was such that the more subjects relied on a left hemisphere mode of thinking (i.e., analytic and verbal processing), the more overgeneral their memories were. Taken together, the results indicate that in normal samples, depression symptoms, neuroticism or trait anxiety do not represent important correlates of overgeneral memories consistent with their status as trait markers uninfluenced by state factors.

\section{Introduction}

A number of recent studies indicate that depressed patients find it difficult to be specific in their autobiographical memories (e.g., Williams and Broadbent, 1986; Williams and Scott, 1988; Moore, Watts and Williams, 1988). The procedure commonly employed in these studies asks depressed and control subjects to retrieve specific autobiographical memories in response to positive (e.g., happy) and negative (e.g., lonely) cue-words. Typically, depressed subjects produce more overgeneral memories (i.e., memories that refer to long time periods and/or repetitive events) than control subjects. This is especially true for positive cue-words.

There are good reasons to believe that the overgeneral memories of depressed patients represent a clinically meaningful phenomenon. For

Reprint requests to Haraid Merckelbach, Department of Experimental Abnormal Psychology, University of Limburg, PO Box 616,6200 MD Maastricht, The Netherlands.

(c) 1996 British Association for Behavioural and Cognitive Psychotherapies 
example, Evans, Williams, O'Loughlin and Howells (1992) reported that the failure of depressed patients to react with detailed memories to cuewords is related to their poor problem-solving capacity. As another example, a longitudinal study of Brittlebank, Scott, Williams and Ferrier (1993) showed that overgeneral recall of autobiographical memories predicts a failure to recover from depression following psychopharmacological intervention.

As to the origins of overgeneral recall, the most articulated hypothesis is that overgeneral memories are the product of a certain cognitive style (Williams, 1992). According to this view, negative life events lead to a cognitive style that focuses on the affective dimensions of experiences. Consequently, more mundane aspects of these experiences are not memorized and this results in overgeneral recall. On the basis of this hypothesis, one would predict that overgeneral recall is not related to a depressed state per se, but represents a stable trait in those patients who have experienced severe life events. In a recent study, Kuyken and Brewin (1995) examined depressed women with or without a history of abuse. In accordance with the prediction summarized above, depressed patients with a history of abuse recalled more overgeneral memories than those without an abuse background. Likewise, McNally and co-workers found that patients with post traumatic stress disorder (PTSD) have more difficulty in recalling specific autobiographical memories than control patients. This was found to be true for Vietnam veterans with PTSD (McNally, Litz, Prassas, Shin and Weathers, 1994; McNally, Lasko, Macklin and Pitman, 1995) and for women with rape- or incest-related PTSD (McNally, Vardi and Orr, 1995). Thus, these studies suggest that overgeneral memories are linked to traumatic events rather than transient mood disturbances.

The hyporhesis that overgeneral memories are tied to particular characteristics (i.e., traumatization; cognitive style) and specific subsamples (i.e., depressed patients; PTSD patients) would gain in strength, if it could be shown that there is no overall correlation between mood and overgeneral memories in a large sample of normal subjects. If, however, such a correlation would exist, then one could argue that overgeneral memories reflect a transient mood disturbance.

The present study examined whether, in a normal sample, depression symptoms and other broad indices of psychopathology (i.e., neuroticism and trait anxiety) are linked to overgeneral memories. In addition, it tentatively explored an alternative view, namely that overgeneral memories are relaced to a preference for certain cognitive operations. That is, one could speculate that a holistic, non-verbal thinking style leads to global memories, whereas an analytic and verbal style leads to highly specific memories. 
Interestingly, these two types of thinking style have been related to hemisphere functioning (e.g., Iaccino, 1993): a verbal and analytic style is commonly ascribed to the left hemisphere, while a global and non-verbal approach is usually attributed to right hemisphere.

\section{Method}

Subjects

Subjects were 194 undergraduates ( 25 men). Their mean age was 20 years (range: 18-29 years). Subjects were given a small financial compensation for their participation in the study.

\section{Measures and procedure}

Subjects were tested in small groups. First, subjects were asked to complete the Beck Depression Inventory (BDI; Beck, Ward, Mendelson, Mock and Erbaugh, 1961), the neuroticism scale of the Eysenck Personality Inventory (N-EPQ; Eysenck and Eysenck, 1964), the trait version of the State-Trait Anxiety Inventory (STAI; Spielberger, Gorsusch and Lushene, 1970), and the Preference Test (PT; Zenhausern, 1978). The BDI is a 21-item selfreport instrument that measures the behavioural manifestations of depression. Neuroticism scores of the N-EPQ (22 items) and trait scores of the STAI (20 items) provide an index of vulnerability to anxiety disorders (see e.g., Eysenck, 1992). The PT is a 20-item paper and pencil test that measures "style of thinking": 10 items address what can be termed a right hemisphere mode of thinking (right hemisphere items; e.g., "I have a good sense of direction") and 10 items address a left hemisphere mode of thinking (left hemisphere items; e.g., "I find it easy to think of synonyms for words"). Subjects use 10-point scales (ranging from 1= "not at all/never" to $10=$ "very much/always") to indicate to what extent the items apply to them. To obtain an index of hemisphere reliance or preference, the score on the right hemisphere items is subtracted from that on the left hemisphere items. Consequently, a positive difference score reflects a relatively strong preference for a left hemisphere thinking style (i.e., an analytic, verbal approach), whereas a negative difference score reflects a relatively strong reliance on a right hemisphere thinking style (i.e., a holistic, non-verbal approach; see Iaccino, 1993). Reliability and factor structure of the PT are encouraging (Merckelbach, Muris, Pool and de Jong, submitted). Furthermore, PT scores covary with other indirect measures of hemisphere reliance (e.g., conjugate lateral eye movements; de Jong, Merckelbach and Muris, 1990).

After subjects had completed the questionnaires, they were given an example of a specific personal memory. Next, they were asked to write down specific autobiographical memories in response to 10 cue-words. Five 
cue-words were positive (i.e., happiness, gaiety, kindness, humour, and intimate) and five were negative (i.e., boredom, sickness, anxiety, misery, and fatigue). Cue-words were taken from Williams and Dritschel (1988) and were read aloud by one of the experimenters (positive and negative cues alternating). Subjects were given two minutes to write down their personal memory. Following the procedure of Williams and Dritschel (1988) as closely as possible, memories were later classified as either general or specific. For each individual, the total number of specific memories (SPEC) was calculated (maximum score $=10$ ). Additionally, the number of specific memories in response to positive (POS) and negative (NEG) cue-words were calculated separately (for both measures: maximum score $=5$ ).

\section{Results}

There was a considerable variation in the total number of specific memories $(M=7.9 ; S D=1.8)$. The same was true for $\mathrm{BDI}(M=5.5 ; S D=4.8), \mathrm{N}-\mathrm{EPQ}$ $(M=5.3 ; S D=2.9)$, trait-STAI $(M=37.7 ; S D=8.6)$, and PT $(M=-2.1$; $S D=11)$. The Pearson correlations between the number of specific memories on the one hand and BDI, N-EPQ, trait-STAI, and PT on the other hand are shown in Table 1. As can be seen, the correlations between the various memory parameters and depression, neuroticism, and trait anxiety failed to attain significance. Curiously enough, there was a negative, but significant association $(r=-.18 ; p=.01)$ between total number of specific memories and $\mathrm{PT}$, indicating that the more subjects rely on a left hemisphere thinking style, the more overgeneral they are in their personal memories. Interestingly, left hemisphere thinking style was also associated with fewer depression symptoms $[r=-.18, p=.01]$, lower neuroticism $[r=-.21$, $p<.01]$ and less trait anxiety $[r=-.20, p<.01]$.

TABLE 1. Pearson product-moment correlations between Preference Test (PT), total number of specific memories (SPEC), total number of "positive" specific memories (POS), total number of "negative" specific memories (NEG), depression (BDI), neuroticism (N-EPQ), and trait anxiety (trait-STAI)

\begin{tabular}{lllll}
\hline & PT & SPEC & POS & NEG \\
\hline SPEC & $-0.18^{*}$ & & & \\
FOS & -0.13 & $0.86^{*}$ & & \\
NEG & $-0.19^{*}$ & $0.88^{*}$ & $0.51^{*}$ & \\
BDI & $-0.18^{*}$ & 0.05 & 0.09 & 0.01 \\
N-EPQ & $-0.21^{*}$ & 0.03 & 0.07 & 0.01 \\
trait-STAI & $-0.20^{*}$ & 0.09 & 0.07 & 0.09 \\
\hline
\end{tabular}

${ }^{*} p \leqslant 0.01, N=194$ (anly relevant correlations are given) 


\section{Discussion}

The main results of the present study can be summarized as follows. Firstly, no evidence was found for a connection between depression or other broad indices of neurotic symptoms (i.e., N-EPQ and trait-STAI) on the one hand and low memory specificity on the other hand. Our failure to obtain such an association in normal subjects corresponds with the results of Williams and Dritschel (1988). In their study, depressed patients were significantly more overgeneral in their memories than normal control subjects. However, within the patient sample, no correlation emerged between measures of mood and overgeneral memory. Also, recovered patients still displayed a reliable tendency to retrieve overgeneral memories. From this, the authors concluded that "there is no evidence that overgeneral recall is mood-dependent" (Williams and Dritschel, 1988; p. 228). Similarly, in their sample of depressed women, Kuyken and Brewin (1995) found no correlation between BDI scores and number of overgeneral memories. Taken together, these findings indicate that overgeneral memories do not represent a state measure linked to transient mood fluctuations (see also Brittlebank et al., 1993). It seems reasonable to conclude that the heightened frequency of overgeneral memories in certain clinical samples has other antecedents than depression per se. Probably, negative life events (e.g., abuse; trauma) play a pivotal role in the origins of overgeneral memories (see also, Kuyken and Brewin, 1995; McNally et al., 1994).

Secondly, the current study found low memory specificity to be related to a left rather than a right hemisphere thinking style. As the correlation between thinking style and memory specificity reached only a moderate magnitude, this finding requires independent replication. One tentative explanation for this unexpected finding could be that subjects were asked to retrieve memories in response to emotional cue-words. Meanwhile, it is known that the right hemisphere is more involved in affective processing than the left hemisphere (e.g., Silberman and Weingartner, 1986). Thus, the relationship between left hemisphere thinking style and low memory specificity might reflect the lack of specialization of this hemisphere for affective processing. Clearly, this post hoc interpretation can only be evaluated with an experimental set-up in which memories are also retrieved in response to neutral cue-words.

Thirdly, in line with previous work (e.g., Merckelbach, Muris and de Jong, 1990; de Jong, Merckelbach and Nijman, 1995), the current study found that individuals with a relatively strong preference for a left hemisphere thinking style have lower scores on broad psychopathology measures (e.g., BDI, N-EPQ, and trait-STAI). 
To sum up, no significant correlation was found between level of depression and overgeneral memories in normal subjects. Therefore, it is very unlikely that depressive mood acts as an important antecedent of overgeneral memories. Yet, the possibility that in normal subjects, cognitive precursors of depression (e.g., attributional style; rumination etc.) are connected to overgeneral memories cannot be ruled out. Clearly this issue warrants further research.

\section{References}

Beck, A. T., Ward, C. H., Mendelson, M., Mock, J. E. and Erbaugr, J. K. (1961). An inventory for measuring depression. Archives of General Psychiatry 4, 561-571 Brittlebank, A. D., Scott, J., Williams, J. M. G. and Ferrier, I. N. (1993). Autobiographical memory in depression: state or trait marker? British Joumal of Psychiatry 162, 118-121.

Evans, J., Williams, J. M. G., O'Loughzin, S. and Howelzs, K. (1992). Autobiographical memory and problem solving strategies of parasuicide patients. Psychological Medicine 22, 399-405.

EYseNCK, M. W. (1992). Anxiety: the cognitive perspective. Hove: Erlbaum.

Ersenck, H. J. and Ersencx, S. B. G. (1964). The Eysenck Personality Inventory. London: University of London Press.

De Jong, P. J., Merckeleach, H. and Muris, P. (1990). Conjugate lateral eye movernents, cerebral dominance, and anxiety. In R. J. Takens (Ed). European perspective in psychology. Vol. 2. New York: Wiley.

De Jong, P. J., Merckelbach, H. and Nijman, H. (1995). Hemisphere preference, anxiety, and covariation bias. Personality and Individual Differences 18, 363-371. IACCINO, J. F. (1993). Left brain-right brain differences: inquiries, evidence, and new approaches. Hove: Erlbaum.

KurkEN, W. and BREwIN, C. R. (1995). Autobiographical memory function in depression and reports of early abuse. Journal of Abnormal Psychology 104, 585-591.

McNalty, R. J., Lasko, N. B., Mackun, M. L. and Prtman, R. K. (1995), Autobiographical memory disturbance in combat-related post traumatic stress disorder. Manuscript submitted for publication.

McNally, R. J., LITz, B. T., Prassas, A., Shin, L. M. and Weathers, F. M. (1994). Emotional priming of autobiographical memory in post traumatic stress disorder. Cognition and Emotion 8, 351-367.

MCNALlY, R. J., VARDI, D. J. and ORR, S. P. (1995). Autobiographical memory disturbance in incest-related and rape-related post traumatic stress disorder. Manuscript submitted for publication.

Merckelback, H., Murrs, P. and DE Jong, P. J. (1990). Hemisphere reference, phobia, and depression. International Joumal of Neuroscience 55, 119-123.

Mercrelbach, H., Muris, P., PoOL, K. and DE Jong, P. J. (submitted). Reliability and validity of a paper-and-pencil test measuring hemisphere preference. 
Moore, R. G., WatTs, F. N. and Wrldtams, J. M. G. (1988). The specificity of personal memories in depression. British Journal of Clinical Psychology 27, $275-276$.

SilBERMAN, E. K. and WeINGARTNER, H. (1986). Hemispheric lateralization of functions related to emotion. Brain and Cognition 5, 322-353.

Spielberger, C. D., Gorsusch, R. L. and Lushene, R. E. (1970). Manual for the State-Trait Anxiety Inventory. Palo Alto, CA: Consulting Psychologists Press. WILI.IAMs, J. M. G. (1992). Autobiographical memory and emotional disorders. In S. A. Christianson (Ed). Handbook of emotion and memory: research and theory. Hillsdale, NJ: Erlbaum.

WILlIAMS, J. M. G. and BROADBENT, K. (1986). Autobiographical memory in suicide attempters. Joumal of Abnormal Psycbology 95, 144-149.

Williams, J. M. G. and Dritscher, B. H. (1988). Emotional disturbance and the specificity of autobiographical memory. Cognition and Emotion 2, 221-234.

WILLIAMS, J. M. G. and SCOTT, J. (1988). Autobiographical memory in depression. Psychological Medicine 18, 689-695.

ZeNhAUSERN, R. (1978). Imagery, cerebral dominance, and style of thinking: a unified field model. Bulletin of the Psychonomic Society 12, 381-384. 